\title{
STRATEGI KOMUNIKASI PARIWISATA PEMERINTAH KOTA BANDUNG MELALUI PROGRAM CO-WORKING SPACE
}

\author{
Gheya Madinatu Sjaida ${ }^{1}$, Awaludin Nugraha ${ }^{2}$, Ute Lies Siti Khadijah ${ }^{3}$, Evi Novianti ${ }^{4}$ \\ Universitas Padjadjaran \\ gheyamsm@gmail.com
}

\begin{abstract}
ABSTRAK
Pariwisata Indonesia semakin menunjukkan daya saingnya dari waktu ke waktu. Hal ini dibuktikan dengan posisi Indonesia yang mengalami kenaikan ke peringkat 40 dari 140 negara di dunia dalam kategori Travel and Tourism Competitiveness Index (TTCI) pada tahun 2019. Prestasi ini diperoleh karena Indonesia terus mengadakan pembenahan dan pembangunan di masing-masing daerah. Salah satu kota yang turut ambil bagian dalam pembangunan pariwisata Indonesia adalah Bandung. Ibukota provinsi Jawa Barat ini semakin menarik perhatian wisatawan. Salah satu program yang dikembangkan saat ini adalah co-working space yaitu sebuah ruangan kerja sama yang ditujukan untuk mengembangkan kemandirian masyarakat dan meningkatkan perekonomian daerah dengan memanfaatkan potensi daerah setempat. Strategi komunikasi adalah paduan dari perencanaan komunikasi (communication planning) dan manajemen komunikasi (communication management) untuk mencapai suatu tujuan (Effendi, 1993: 301). Perencanaan dan pelaksanaan co-working space di Kota Bandung menjadi sarana komunikasi yang diharapkan mampu menunjang pembangunan potensi pariwisata. Penelitian ini menggunakan metode deskriptif dengan pendekatan kualitatif. Tujuan dari penelitian ini adalah menggambarkan strategi komunikasi pariwisata yang dilakukan Pemerintahan Kota Bandung untuk membangkitkan potensi wisata baru, memunculkan kemandirian dan meningkatkan perekonomian daerah.
\end{abstract}

Kata Kunci: Strategi Komunikasi, Komunikasi Pariwisata

\section{ABSTRACT}

Indonesian tourism is increasingly showing its competitiveness from time to time. This is evidenced by Indonesia's position which has increased to 40th out of 140 countries in the world in the category of Travel and Tourism Competitiveness Index (TTCI) in 2019. This achievement was obtained because Indonesia continues to hold improvements and development in each region. One of the cities that took part in the development of Indonesian tourism is Bandung. The capital of West Java province is increasingly attracting the attention of tourists. One program that is being implemented and continues to be developed is co-working space as a space for cooperation aimed at developing community independence and improving the regional economy by utilizing the potential of the local area. Communication strategy is a combination of communication planning (communication planning) and communication management (communication management) to achieve a goal (Effendi, 1993: 301). Planning and implementing co-working space in the city of Bandung is a means of communication that is expected to support the development of tourism potential. This research uses descriptive method with a qualitative approach. The purpose of this study is to describe the tourism communication strategy undertaken by the Bandung City Government to generate new tourism potential, bring independence and improve the regional economy.

Keywords: Communication Strategy, Tourism Communication

\footnotetext{
${ }^{1}$ Mahasiswa Magister Pariwisata Berkelanjutan, Universitas Padjadjaran

2 Dosen Magister Pariwisata Berkelanjutan, Universitas Padjadjaran

${ }^{3}$ Dosen Magister Pariwisata Berkelanjutan, Universitas Padjadjaran

${ }^{4}$ Dosen Magister Pariwisata Berkelanjutan, Universitas Padjadjaran
} 


\section{PENDAHULUAN}

Wisata menjadi salah satu aspek kehidupan yang semakin dibutuhkan. Aktivitas harian yang tidak ada habisnya hingga akibat kemacetan lalu lintas membuat hampir setiap kalangan memerlukan waktu khusus untuk menyegarkan diri. Kondisi ini membuat daerahdaerah wisata di Indonesia terus mengadakan pembenahan dan menyuguhkan potensi wisata baru. Pembenahan yang berkelanjutan ini membawa Indonesia ke posisi 40 besar dari 140 negara di dunia dalam kategori Travel and Tourism Competitiveness Index (TTCI) pada tahun 2019. Sebuah prestasi yang membanggakan mengingat kekayaan alam yang ada di Indonesia sangat melimpah. ${ }^{5}$

Prestasi gemilang dalam bidang pariwisata juga turut dirasakan oleh Kota Bandung. Penghargaan Indonesia Attractiveness Award (IAA) 2019 Kategori Kota Besar Terbaik Sektor Pariwisata Indonesia peringkat Gold baru saja dimenangkan oleh Kota Bandung. Penghargaan tersebut diterima oleh Walikota Bandung, Oded M. Danial di Pullman Hotel Jakarta pada 23 Juli 2019. Walikota menyatakan bahwa penghargaan ini menjadi pemacu pemerintah Kota Bandung dalam meningkatkan kinerja dan potensi pariwisata yang ada di wilayahnya. Hal senada diungkapkan Kepala Dinas Kebudayaan dan Pariwisata Kota Bandung, Dewi Kaniasari. Beliau menyatakan bahwa pelayanan perlu ditingkatkan serta atraksi dan ekonomi kreatif yang menjadi kalender kegiatan perlu diperbanyak. Pariwisata

\footnotetext{
5 Mico Desrianto, "Menpar Sumringah Posisi Indonesia di Peringkat Pariwisata Dunia Naik", https://travel.kompas.com/read/2019/09/06/11433412 7/menpar-sumringah-posisi-indonesia-di-peringkatpariwisata-dunia-naik?page $=$ all (diakses pada 23 Oktober 2019 pukul 14.30)
}

yang ditonjolkan di Kota Bandung bukan merupakan wisata alam seperti potensi alam kota lainnya. Kota Bandung hadir dengan Man Made Tourism (pariwisata buatan manusia). Pariwisata buatan ini tampak dalam rupa taman tematik dan ruang publik yang dapat digunakan secara gratis oleh masyarakat dan juga wisatawan. CEO Tempo Media Group, Toriq Hadad menyampaikan bahwa kategori penghargaan Indonesia Attractive Award 2019 merupakan kategori yang ditujukan untuk memotivasi seluruh daerah untuk membangun strategi-strategi yang lebih terarah dan jelas.

Setiap daerah ditantang untuk menunjukkan hasil pembangunannya masingmasing. Demikian halnya dengan pemerintah Kota Bandung yang semakin terpacu meningkatkan kinerjanya. Hal ini terlihat dari strategi komunikasi yang digunakan pemerintah Kota Bandung dalam memperkenalkan potensi wisata daerahnya melalui Humas. Saat ini Humas Pemerintah Kota Bandung memanfaatkan website dan media sosial untuk menyampaikan beragam informasi terkait perkembangan kota termasuk sektor pariwisatanya. Website dan media sosial ini diharapkan mampu menjadi sumber informasi terpadu dan terpercaya yang bisa dimanfaatkan untuk mengenalkan Bandung secara lebih luas.

Selain itu, pemerintah bekerja sama dengan akademisi dari berbagai perguruan tinggi, komunitas, pengusaha lokal, serta masyarakat setempat untuk menggali potensi hingga kesiapan wilayah dalam menghadapi persaingan pariwisata. Pemerintah juga mengapresiasi setiap pihak yang telah memberikan pelayanan terbaiknya untuk memajukan sektor pariwisata Bandung. Apreasiasi ini diharapkan mampu menjadi 
penyemangat agar setiap pihak yang terlibat dalam dunia pariwisata Bandung dapat terus memberikan pelayanan terbaik bagi wisatawan. Strategi-strategi komunikasi yang digunakan oleh Pemerintah Kota Bandung bertujuan untuk mengenalkan dan memajukan potensi wisata yang ada melalui beragam aktivitas dan penyampaian informasi yang berimbang. Strategi ini tidak dapat dilakukan sendiri, perlu adanya kerja sama dengan berbagai pihak yang memiliki kredibilitas dalam melaksanakan program pemerintah. Salah satu program yang kini menjadi perhatian besar pemerintah Kota Bandung dalam menciptakan destinasi pariwisata baru adalah co-working space. Program ini merupakan tempat kerja bersama yang bertujuan untuk mengembangkan potensi di daerah tersebut.

Strategi komunikasi yang dilakukan pemerintah Kota Bandung juga diselaraskan dengan bidang-bidang kajian komunikasi pariwisata. Penyelarasan ini dilakukan mengingat fokus utama pelaksanaan co-working space adalah menciptakan destinasi wisata baru dengan daya tarik unik di setiap daerahnya. Bidang-bidang kajian inilah yang akan menjadi acuan pemerintah dan setiap pihak yang terlibat untuk menjalankan program pengembangan ini.

\section{METODE PENELITIAN}

Metode yang digunakan dalam
penulisan ini adalah deskriptif dengan
pendekatan kualitatif. Menurut Usman (2009: 4)
penelitian dengan menggunakan metode
deskriptif bermaksud membuat penyandaraan
secara sistematis, faktual, dan akurat mengenai
fakta-fakta dan sifat-sifat populasi tertentu.
Sedangkan menurut Nawawi (2003:63),
penelitian deskriptif merupakan prosedur

pemecahan masalah yang diselidiki dengan menggambarkan atau melukiskan keadaan subjek atau objek penelitian berdasarkan fakta yang tampak sebagaimana adanya.

Bob dan Taylor, mendefinisikan pendekatan kualitatif adalah prosedur penelitian yang menghasilkan data deskriptif berupa katakata tertulis atau lisan dari orang-orang dan perilaku yang dapat diamati (Moleong, 2005). Penelitian kualitatif adalah penelitian untuk menjawab permasalahan yang memerlukan pemahaman secara mendalam dalam konteks waktu dan situasi yang bersangkutan, dilakukan secara wajar dan alami sesuai dengan kondisi objektif di lapangan tanpa adanya manipulasi, serta jenis data yang dikumpulkan terutama data kualitatif (Arifin, 2012).

\section{HASIL DAN PEMBAHASAN}

Minat wisatawan terhadap daya tarik wisata Kota Bandung semakin hari semakin meningkat. Hal ini disebabkan oleh banyaknya pilihan jenis wisata yang dapat dikunjungi, mulai dari wisata kuliner, busana, taman tematik, hingga wisata keliling kota dengan menggunakan bus (Bandros). Tingginya minat wisatawan ini mendapat respon positif dari pemerintah Kota Bandung, salah satunya dengan menciptakan co-working space. Coworking space merupakan tempat kerja bersama yang akan menjadi pusat pengembangan ekonomi di setiap kecamatan. Kepala Bidang Ekonomi Kreatif Dinas Kebudayaan dan Pariwisata (Disbudpar) Kota Bandung, Tris Avianti menyatakan bahwa dari 30 kecamatan di Kota Bandung, saat ini sudah 11 kecamatan yang siap dengan co-working space. Pemerintah Kota Bandung juga bekerja sama dengan Universitas Padjadjaran untuk mengkaji 
kesiapan setiap kecamatan. Hasil kajian tersebut menunjukkan bahwa Kecamatan Rancasari, Cibiru, Sumur Bandung, Mandalajati, Ujung Berung, Batununggal, Bandung Wetan, Astananyar, Arcamanik, Lengkong, dan Kecamatan Cibeunying Kidul sudah siap untuk memulai co-working space. ${ }^{6}$

Pemerintah Kota Bandung menggunakan co-working space sebagai strategi komunikasi yang sesuai untuk mengembangkan potensi pariwisata baru. Setiap daerah di Kota Bandung memiliki potensi-potensi unik yang dapat digali dan dikembangkan menjadi daerah wisata baru sehingga di kemudian hari juga dapat meningkatkan tingkat perekonomian masyarakat setempat.

Menurut Littlemore (2003:1) dalam The Communicative Effectiveness of Diferent Types of Communication Strategy menjelaskan bahwa strategi komunikasi merupakan langkahlangkah yang harus diambil di dalam meningkatkan efektifitas komunikasi. Sedangkan menurut Effendi (1993: 301) strategi komunikasi adalah paduan dari perencanaan komunikasi (communication planning) dan manajemen komunikasi (communication management) untuk mencapai suatu tujuan. Strategi komunikasi harus dapat menunjukan operasional secara taktis harus dilakukan, dalam arti kata bahwa pendekatan (approach) bisa berbeda sewaktu-waktu bergantung pada situasi dan kondisi agar tujaun dapat tercapai. Berdasarkan definisi tersebut dapat disimpulkan

${ }^{6}$ Humas Bandung, "Kecamatan Sumur Bandung Jadi Proyek Percontohan Co-Working Space", http://humas.bandung.go.id/humas/berita/2019-1015/kecamatan-sumur-bandung-jadi-proyekpercontohan-co (diakses pada 22 Oktober 2019 pukul 13.08) bahwa strategi komunikasi merupakan langkah perencanaan dan pengelolaan yang diambil untuk mencapai tujuan bersama. Strategi komunikasi konsep Harold D. Laswell (1960) sebagaimana dikutip oleh Effendi (1986: 37) menjelaskan bahwa untuk bisa memahami strategi komunikasi maka harus mampu menjawab pertanyaan-pertanyaan berkaitan dengan komunikator, pesan yang inign dinyatakan, media yang digunakan, komunika dari proses komunikasi, serta efek yang diharapkan.

Cutlip (2007: 392-407) menerangkan bahwa agar lebih mudah dalam melakukan dan mempraktikan strategi komunikasi, maka pelaksana harus mengetahui langkah taktis strategi komunikasi supaya mencapai tujuan yang diinginkan. Langkah-langkah tersebut adalah membingkai pesan, semantik, simbol, rintangan dan stereotip, memasukkan semua ke dalam kampanye, menyebarkan pesan, dan mempertimbangkan kembali proses.

Co-working space menjadi salah satu bentuk daya tarik pariwisata baru yang dikembangkan di Kota Bandung. Co-working space atau tempat kerja bersama yang digagas oleh Walikota dan Wakil Walikota Bandung ini, akan menjadi pusat pengembangan ekonomi di setiap kecamatan. Masing-masing kecamatan akan membuat co-working space tematik sesuai dengan potensi yang ada di wilayahnya. Pemerintah perlu memperhatikan cara menyampaikan informasi yang tepat agar masyarakat daerah tersebut dapat memahami tujuan dari program. Pandangan dan kebutuhan masyarakat perlu digali agar pelaksanaan program ini dapat berlangsung dengan maksimal. Cara yang dilakukan untuk mampu memahami hal tersebut. Diskusi ini diharapkan 
mampu menjadi sarana untuk menyampaikan pesan dari program yang dilaksanakan agar selaras dengan harapan dan kebutuhan masyarakat setempat.

Pemerintah Kota Bandung juga perlu mempertimbangkan penggunaan bahasa yang sesuai dengan masyarakat. Penggunaan bahasa yang sesuai akan memudahkan komunikan (masyarakat setempat) untuk memahami pesan yang disampaikan. Bahasa Sunda sebagai daerah digunakan sebagai sarana komunikasi dengan warga karena mayoritas masyarakatnya masih menggunakan bahasa daerah sebagai bahasa sehari-hari. Selain itu Bahasa Indonesia tetap digunakan dalam proses komunikasi karena ada beberapa istilah yang lebih mudah dipahami dalam bahasa aslinya.

Selain cara menyampaikan pesan dan bahasa yang digunakan dalam proses komunikasi, pelaksanaan pengembangan coworking space ini juga memerlukan pemahaman terhadap simbol-simbol yang stereotip yang tumbuh di tengah masyarakat Co-working space meliputi kegiatan inkubasi dan berbagai pelatihan, yaitu pelatihan pemandu wisata, melukis, menari tradisi, dan pembuatan aneka kerajinan tangan. Pemahaman yang tepat terhadap nilai-nilai tradisi (local wisdom) yang ada di daerah tersebut mampu mempermudah penerimaan informasi oleh masyarakat.

Tim mentor juga menggunakan ruang diskusi warga berupa Balai Warga sebagai simbol bahwa inovasi yang akan dilaksanakan tetap akan didasarkan pada nilai-nilai luhur budaya yang sudah ada. Contohnya adalah tim mentor yang menggunakan balai warga RW 08 Kelurahan Braga sebagai tempat diskusi, persiapan, serta pelaksanaan co-working space di Kecamatan Sumur Bandung. Dengan demikian pelaksanaan co-working dapat dilakukan dengan alami tanpa perlu melanggar simbol-simbol yang ada sebelumnya. Hal ini sejalan dengan hasil penelitian mengenai cara memaksimalkan potensi wisata alam di Jawa Barat yang yang diperoleh Nardi pada tahun 2005. Hasil penelitian menyimpulkan bahwa kegiatan wisata harus memperhatikan prinsip partisipasi masyarakat, hak budaya lokal, aspek konservasi sumber daya, pendidikan dan pelatihan, promosi, akuntabilitas serta pemantauan dan evaluasi.

Konsep lanjutan yang menjadi perhatian setiap daerah adalah local branding dan place baranding. Local branding yang dimaksud adalah pelabelan yang memiliki kekuatan untuk membantu penjualan suatu lokasi atau tempat tertentu kepada publik. Dengan kata lain, local branding diawali dari suatu branding dalam artian adalah sebuah usaha untuk memperkuat posisi suatu produk dalam benak konsumen dengan cara menambahkan equity dari nama sekumpulan produk (Soemanagara, 2008: 98). Konsep local branding dan place branding nilah yang digunakan oleh Aat Ruchiat Nugraha dkk dalam penelitiannya mengenai Model Komunikasi Pariwisata yang Berbasiskan Kearifan Lokal. Hasil penelitian menunjukkan bahwa model komunikasi pariwisata di kawasan Lembang yang berbasiskan kearifan local adalah dengan mempertautkan antara tujuan pembangunan destinasi wisata dengan local branding dan place branding suatu objek wisata melalui penyetaraan peran dan fungsi kelompokkelompok yang berkepentingan dalam sebuah pendekatan bottom up system yang berbasiskan nilai sosial budaya dan keindahan panorama alam, di mana keberadaan masyarakat menjadi 
basis normatif dan bertindak sebagai fasilitator yang memampukan sumber daya alam dan lingkungan sosial masyarakat dalam satu kesatuan kebijakan pengelolaan objek wisata.

Pelaksanaan strategi komunikasi dalam suatu program tentu tidak terlepas dari hambatan terutama mengenai isi dari pesan yang ingin disampaikan. Hambatan untuk menjelaskan pesan ada di pihak komunikator dan audiennya. Seperti dicatat Lippmann, setiap orang tinggal di dalam lindungan (kepompong) lingkungannya sendiri-sendiri. Kepompong ini menyekat individu dari serbuan informasi yang tak ada hentinya dan semakin meningkat intensitasnya. Merujuk pendapat Cangara, terdapat lima prinsip untuk mendasari penyusunan perencanaan yang ideal adalah prinsip partisipatif, prinsip kesinambungan, prinsip holistic, mengandung sistem yang berkembang, terbuka dan demokratis (Cangara, 2013: 31). Namun jika dibandingkan dengan kenyataan pada hasil temuan penelitian bahwa, prinsip perencanaan yang partisipatif dan demokratis belum sepenuhnya dilaksanakan. Ada rintangan sosial, rintangan usia, rintangan bahasa atau kosakata, serta rintangan ekonomi dan politik. Ada rintangan ras; rintangan dan distorsi yang menutup komunikasi tampak jelas dalam perbedaan antar kelompok etnis dan ras di masyarakat Amerika yang multicultural. Sama halnya di Indonesia tentunya yang juga memiliki keanekaragaman suku ras dan kepercayaan. Juga ada rintangan yang sering dilupakan yakni, kemampuan atau kesediaan audien untuk menyerap pesan. Terakhir ada persaingan untuk mendapatkan perhatian orang di arena publik.
Komunikasi pariwisata memiliki beberapa bidang kajian utama yang dapat dikembangkan sebagai bidang-bidang kajian yang menarik. Bidang-bidang ini akan terus berkembang diwaktu-waktu yang akan datang sejalan dengan berkembangnya kompleksitas kajian di komunikasi pariwisata. Bidang-bidang yang dimaksud oleh Burhan Bungin (2015), antara lain: komunikasi pemasaran, brand destinasi, manajemen komunikasi pariwisata, komunikasi transportasi pariwisata, komunikasi visual pariwisata, komunikasi kelompok pariwisata, komunikasi online pariwisata, Public Relations (PR) dan MICE, serta riset komunikasi pariwisata.

Dalam komunikasi, tak ada yang lebih menyulitkan ketimbang kenyataan bahwa kebanyakan audien media massa punya akses terbatas terhadap fakta. Dengan akses yang terbatas dan dengan beberapa informasi yang membingungkan ketimbang menjelaskan, orang sangat mengandalkan pada stereotip. Kesan spesifik dan signifikan menjadi sesuatu yang sangat umum atau digeneralisir. Oleh karena itu diperlukan proses komunikasi yang sesuai dengan masing-masing daerah.

Strategi komunikasi berupa co-working space ini tidak selalu berjalan mulus. Ada hambatan berupa pihak-pihak yang sulit diajak untuk berdiskusi, tidak berminat terhadap pesan yang disampaikan, hingga menghindari informasi yang tidak sesuai dengan pemikiran. Kondisi ini tidak menghalangi tim untuk terus mengembangkan potensi pariwisata di setiap kecamatan di Kota Bandung agar tingkat kesejahteraan masyarakat pun mengalami peningkatan. Pesan yang disampaikan dalam proses komunikasi ini pun diarahkan untuk membuka pola pikir dan mengembangkan 
motivasi masyarakat agar menjadi wilayah yang mandiri. Kepala Bidang Ekonomi Kreatif Dinas Kebudayaan dan Pariwisata (Disbudpar) Kota Bandung, Tris Avianti, menyatakan bahwa operasional co-working space bekerja sama dengan Lembaga Pemberdayaan Masyarakat (LPM), Karang Taruna, kader PKK dan elemen masyarakat lain agar lebih banyak menjaring partisipasi. Selain itu tim juga bekerja sama dengan OPD (Organisasi Perangkat Daerah), seperti Disdagin, KUKM, Dispangtan, Dispora DP3APM. Stakeholder pengusaha dari HIPMI sudah siap, dan media tentu saja mendukung menggunakan konsep pentahelix.

Sementara itu, Wakil Dekan Fakultas Teknologi Industri Pertanian (FTIP) Unpad, Dwi Purnomo yang ikut berkolaborasi sebagai mentor menyatakan, penekanan co-working space di level kecamatan ini bukan hanya persoalan pengadaan tempat semata. Coworking space lebih menekankan pada ruang interaksi untuk masyarakat agar semakin meningkatkan kemandirian terutama di bidang ekonomi. Co-working space menjadi program pemberdayaan yang bisa dielaborasi oleh semua kalangan, mulai dari anak-anak, pemuda, hingga orang tua. Pihak-pihak yang ditunjuk untuk bekerja sama untuk mendukung program pemberdayaan ini memiliki kredibilitas sehingga mampu meyakinkan masyarakat untuk terlibat aktif. Semakin banyak warga yang terlibat maka semakin banyak potensi daerah yang bisa dikembangkan. Kondisi ini sejalan dengan dampak positif berupa banyaknya jenis usaha yang diperoleh para pedagang di agrowisata Gunung Mas. Hasil dari penelitian yang dilaukan oleh Ajrina Nur Alifah pada tahuan 2014 ini menunjukkan bahwa kegiatan ekonomi di agrowisata Gunung Mas dapat meningkatkan kesejahteraan secara bertahap.

Beberapa penelitian yang dilakukan sebelumnya mengenai strategi komunikasi pada suatu program menunjukkan ada serangkaian komunikasi yang perlu ditingkatkan kembali. Sinergi masing-masing pihak dala melaksanakan program, peningkatan kapasitas penerima dan pemberi program, sistem jaringan yang handal berbasis ITE, serta monitoring dan evaluasi kegiatan komunikasi program menjadi catatan penting Ali Alamsyah Kusumadinata dan Maria Fitriah ketika meneliti mengenai strategi komunikasi pelayanan publik melalui program pos pemberdayaan keluarga.

Pembinaan yang terus-menerus serta motivasi yang terus diasah melalui serangkaian komunikasi yang bersifat persuasif dan informatif perlu ditingkatkan kembali. Implikasi dari penelitian ini adalah (1) perlu sinergi masing-masing program

posdaya dalam membangun pemberdayaan khususnya berkenaan langsung dengan kebutuhan dasar masyarakat, (2) perlunya peningkatan kapasitas aktor pembangunan baik dari penerima program maupun pemberi program, (3) perlunya program yang berbasis problematik masyarakat dengan didasarkan pada keberlanjutan program. (4) sukses tidaknya pemberdayaan masyarakat berdampak pada pelayanan publik yang baik, dibutuhkan strategi komunikasi yang sesuai dengan waktu yang tepat dan tipologi masyarakat sendiri. (5) perlunya networking suatu sistem jaringan yang handal dengan menggunakan pendekatan media yang berbasis ITE dalam mengembangkan pemberdayaan masyarakat yang mendekatkan layanan kepada publik itu sendiri. (6) perlunya monitoring dan evaluasi kegiatan komunikasi 
dengan pendekatan audit komunikasi agar strategi yang dijalankan sesuai dengan tujuan proram pembangunan suatu daerah.

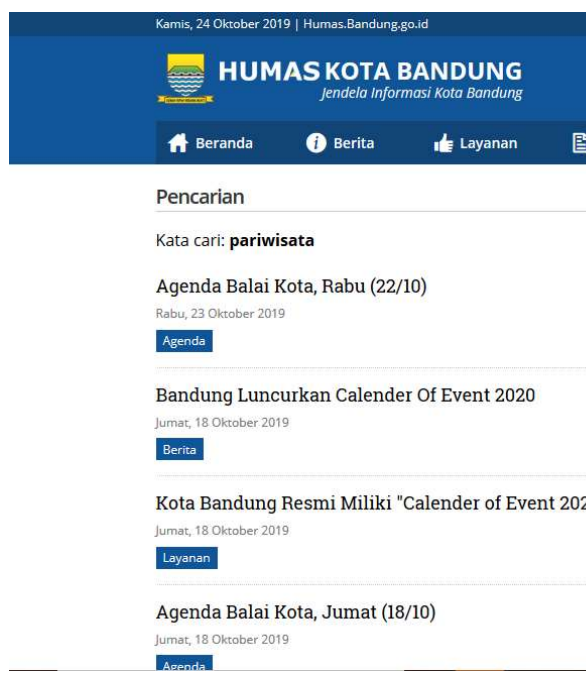

Gambar 1 Tampilan website resmi Humas

Kota Bandung

Sumber: www.humas.bandung.go.id

Program co-working space yang saat

ini tengah dilaksanakan menjadi potensi pariwisata baru di Kota Bandung. Oleh karena itu diperlukan strategi komunikasi yang tepat untuk memperkenalkannya pada masyarakat. Pemerintah Kota Bandung menggunakan website resmi Humas Bandung yaitu humas.bandung.go.id dan media sosial instagram dengan nama akun @humasbdg sebagai media untuk menyampaikan berbagai informasi, salah satunya berkaitan dengan bidang pariwisata. Fungsi dari strategi komunikasi adalah menyebarluaskan pesan komunikasi yang besifat informatif, persuasif dan instruktif secara sistematik kepada sasaran untuk memperoleh hasil optimal serta menjembatani cultural gap akibat kemudahan diperolehnya dan kemudahan dioperasionalkannya media massa yang begitu ampuh. Strategi komunikasi ini perlu ditunjang oleh media yang sesuai dan efektif dalam menyampaikan informasi. Era digital saat ini telah memberikan kemudahan bagi masyarakat dalam memperoleh informasi yang diinginkan.

Informasi yang disampaikan melalui website dan media sosial Kota Bandung telah terbukti kualitasnya. Hal tersebut terlihat dari prestasi yang diterima oleh Bagian Humas Setda Kota Bandung yang berhasil meraih Penghargaan Anugerah Media Humas (AMH) 2018 yang diselenggarakan oleh Kementerian Informasi dan Komunikasi (Kemenkominfo). Bagian Humas meraih penghargaan sebagai Juara Terbaik I kategori Media Sosial dan Juara Terbaik III kategori Pelayanan Informasi Melalui Internet (Website). Pemerintah menjadikan kedua media ini sebagai sarana pelayanan informasi yang mudah dan cepat bagi masyarakat. Selain itu juga sebagai sarana untuk mengontrol kinerja penyelenggaraan pemerintah, termasuk dalam bidang program pengembangan pariwisata daerah.

Humas pemerintah Kota Bandung berperan aktif dalam menyampaikan beragam informasi berkaitan dengan kota. Humas pemerintah memiliki peranan yang sedikit berbeda dengan public relations perusahaan pada umumnya. Humas dalam pemerintah merupakan kelanjutan dari proses penetapan kebijaksanaan, pemberian pelayanan kepada masyarakat dengan sikap yang disesuaikan dengan kepentingan orang atau golongan agar lembaga atau instansi dimana Humas itu berada memperoleh kepercayaan dari publiknya, yaitu masyarakat dalam arti luas. Pelayanan dan sikap yang baik sangat penting demi terciptanya pengertian dan penghargaan yang sebaikbaiknya.

Humas pemerintah bertugas memberikan informasi dan penjelasan kepada 
khalayak atau publik mengenai kebijakan dan langkah-langkah atau tindakan yang diambil oleh pemerintahserta mengusahakan tunbuhnya hubungan yang harmonis antara lembaga atau instansi dengan publiknya dan memberikan pengertian kepada masyarakat tentang apa yang dikerjakan oleh instansi pemerintah dimana humas tersebut berada dan berfungsi. Jadi pada dasarnya tugas humas pemerintah adalah memberikan penerangan dan pendidikan kepada masyarakat tentang kebijakan, langkah-langkah dan tindakan-tindakan pemerintah, serta memberikan pelayanan terhadap masyarakat berupa informasi yang diperlukan secara terbuka, jujur dan objektif; memberi bantuan kepada media berita (news media) berupa bahan-bahan informasi mengenai kebijakan dan langkah-langkah serta tindakan pemerintah, termasuk fasilitas peliputan kepada media berita untuk acara-acara resmi yang penting.; mempromosikan kemajuan pembangunan ekonomi dan kebudayaan yang telah dicapai oleh bangsa kepada khalayak luar negeri; dan memonitor pendapat umum tentang kebijakan pemerintah selanjutnya menyampaikan tanggapan masyarakat dalam bentuk feedback. Pemerintah merupakan sumber informasi penting bagi media, karena itu sikap keterbukaan informasi sangat dibutuhkan. (Rahmadi, 1999: 78).

Penggunaan media baru seperti twitter, facebook, dan situs internet juga dimanfaatkan oleh pemerintah Kota Cirebon dan pihak swasta untuk dapat mengenalkan objek-objek dan atraksi-atraksi wisata yang ada di daerah ini agar para pendatang tersebut dapat tinggal lebih lama. Promosi yang dilakukan melalui pembuatan situs dilakukan oleh pihak keraton kasepuhan dengan http: //kasepuhan.com dan juga dilakukan oleh pemerintah daerah melalui http://www.disporbudpar.cirebonkota.go. id. Selain itu, ada pihak swasta yang bergerak dalam industri pariwisata membuat akun twitter khusus untuk memperkenalkan segala informasi tentang Cirebon melalui @boutcirebon. Kota Cirebon adalah salah satu daerah tujuan wisata di Provinsi Jawa Barat. Kota Cirebon adalah sebuah kota mandiri terbesar kedua di Provinsi Jawa Barat, setelah ibu kota Jawa Barat, yakni Kota Bandung. Kota ini beradadi pesisir Laut Jawa, di jalur pantura. Jalur Pantura JakartaCirebon-Semarang merupakan jalur terpadat di Indonesia. Kota Cirebon juga adalah kota terbesar keempat di wilayah Pantura setelah Jakarta, Surabaya, dan Semarang. Karena letaknya yang sangat strategis yakni di persimpangan antara Jakarta, Bandung, dan Semarang, menjadikan kota Cirebon sangat cocok dan potensial untuk berinvestasi dalam segala bidang investasi seperti hotel, rumah makan, pusat perbelanjaan baru, dan pendidikan.

Pemerintah Kota Bandung dengan sepenuh hati menggunakan setiap potensi yang dimiliki untuk mengembangkan destinasi pariwisata baru. Setiap tahap yang dilakukan mulai dari perencanaan hingga pelaksanaan dipersiapkan dengan maksimal. Pemerintah juga memperhatikan bidang-bidang komunikasi pariwisata yang akan mengalami perkembangan di kemudian hari. Hal tersebut terlihat dari kegiatan pemasaran yang dilakukan dengan memperkenalkan co-working space di Kecamatan Sumur Bandung yang telah siap untuk dikembangkan. Setiap tahapan program dikelola dengan maksimal agar strategi komunikasi yang dilakukan dapat berjalan dengan maksimal. Pemerintah juga 
menggunakan media online untuk memudahkan masyarakat dala mengakses informasi yang lengkap dan terpercaya. Humas Pemerintah Kota Bandung pun digerakkan untuk mendukung kesuksesan program co-working space di berbagai kecamatan menjadi destinasi pariwisata baru. Selain itu tim juga melakukan riset mendalam sebelum melakukan strategi komunikasi agar setiap langkah yang diambil dapat mencapai tujuan bersama dengan lebih efektif dan efisien.

\section{KESIMPULAN}

Kota Bandung menjelma menjadi sebuah kota dengan beragam pilihan destinasi wisata. Minat wisatawan untuk mengunjungi Kota Kembang ini semakin tinggi sejak pemerintah kota secara khusus melakukan pengembangan terhadap bidang pariwisata. Strategi komunikasi pariwisata dipilih menjadi cara untuk menyampaikan program pariwisata baru yang tengah dikembangkan oleh pemerintah yaitu co-working space. Program pengembangan daerah wisata berupa coworking space ini dilakukan di setiap kecamatan dengan menggali setiap potensi dan keunikan sumber daya yang ada di dalamnya. Masingmasing kecamatan nantinya akan memiliki keunikan wisata berdasarkan potensi daerahnya. Strategi komunikasi pariwisata yang dilakukan sejak perencanaan ini sangat memperhatikan isi dan cara penyampaian pesan yang efektif. Hal ini disebabkan oleh perbedaan pola pikir masyarakat dalam mencerna informasi.

Selain itu pihak yang menyampaikan pesan juga sangat penting diperhatikan karena masyarakat masih melihat sosok dari pemberi informasi. Pemerintah kota mengatasi kondisi ini dengan cara menjalin kerja sama dengan beragam kalangan, mulai dari akademisi,
Lembaga Pemberdayaan Masyarakat (LPM), Karang Taruna, kader PKK dan elemen masyarakat lain. Tujuan dari kerja sama ini adalah untuk meningkatkan partisipasi masyarakat dalam program co-working space. Pelaksanaan program pengembangan daerah wisata baru ini juga turut disampaikan melalui website resmi humas.bandung.go.id. Informasi yang disampaikan melalui media resmi pemerintah kota diharapkan mampu memberikan pengetahuan baru bagi masyarakat luas mengenai program-program yang akan dan sedang dilaksanakan.

Pelaksanaan strategi komunikasi pariwisata yang dilakukan oleh Pemerintah Kota Bandung belum sepenuhnya berjalan dengan lancar. Masih ada kendala-kendala yang dihadapi dalam selama melaksanakan program di lapangan. Kendala-kendala tersebut meliputi kesediaan masyarakat untuk terlibat dalam program co-working space, menemukan potensi yang dapat menarik perhatian wisatawan untuk datang, serta menjalin kesepahaman dengan seluruh pihak yang terlibat dalam pengembangan program ini. Kendala-kendala inilah yang terus dibenahi dan dicari jalan keluarnya agar tujuan bersama yaitu membangkitkan kemandirian dan meningkatkan perekonomian daerah melalui sektor pariwisata dapat terpenuhi. Strategi komunikasi yang efektif dan efisien tidak dapat dilakukan oleh satu pihak saja, diperlukan kerja sama tim untuk mencapai tujuan yang diharapkan. Oleh karena itu pemerintah Kota Bandung secara bertahap membina kecamatan demi kecamatan agar mampu mandiri dan mengalami peningkatan ekonomi setelah diterapkannya co-working space. 
Penentuan jenis kegiatan promosi sampai pada pelaksanaan promosi, waktu pelaksanaan dan tempat/lokasi pelaksanaan promosi perlu diperhatikan kembali oleh pemerintah kota. Faktor-faktor yang menjadi pendukung dalam pelaksanaan strategi komunikasi seperti sumber daya manusia dan potensi daerah yang dimiliki perlu ditingkatkan agar semakin banyak wisatawan yang menyadari keberadaan co-working space. Koordinasi yang baik antara tim dan warga setempat perlu dijaga sehingga tercipta kesepahaman terhadap program yang sedang berjalan. Hal-hal tersebut menjadi sangat penting mengingat co-working space merupakan program berkesinambungan yang berhubungan dengan berbagai pihak, baik pemerintah kota, stakeholder, warga, dan pihak swasta.

\section{DAFTAR PUSTAKA}

Allifah, A. N. (2014). Dampak Agrowisata Terhadap Pendapatan Para Pedagang di Agrowisata Gunung Mas PTPN VIII. Jurnal Agric. Sci. J., 1 (4), 91-99.

Arifin, Z. (2012). Penelitian Pendidikan dan Paradigma Baru. Bandung: PT Remaja Rosdakarya.

Bungin, B. (2015). Komunikasi Pariwisata (Tourism Communication): Pemasaran dan Brand Destinasi. Jakarta: Prenadamedia Group.

Cangara. H. Hafied. (2013). Perencanaan dan Strategi Komunikasi. Jakarta: PT Raja Grafindo Persada.

Cutlip, S. M., Center, A. H., \& Broom, d. G. (2007). Effective Public Relations. Jakarta: Kencana.

Effendy, O. U. (1993). Ilmu, Teori, dan Filsafat Komunikasi. Bandung: PT Citra Aditya Bakti.

- (1998). Ilmu Komunikasi Teori dan Praktek. Bandung: PT Remaja Rosda Karya.

Hadari, N. (2003). Metode Penelitian Bidang Sosial. Yogyakarta: Gajah Mada University Press.
Lasswell, H. (1960). The Structure and Function of Communication in Society. Urbana: University of Illinois Press.

Littlemore, J. (2003). The Communicative Effectiveness of Different Types of Communication Strategy.

Kusumadinata, Ali Alamsyah., \& Fitriah, Maria. (2017). Strategi Komunikasi Pelayanan Publik

Melalui Program Pos Pemberdayaan Keluarga. Jurnal ASPIKOM, 3 (2), 225-238.

Moleong, L. J. (2005). Metodologi Penelitian Kualitatif. Bandung: PT Remaja Rosdakarya.

Nardi. (2005). Memaksimalkan Potensi Wisata Alam di Jawa Barat. Jurnal Manajemen Resort dan Leisure, 1 (1).

Nugraha, Aat Ruchiat., Perbawasari, Susie., \& Feliza Zubair. (2017). Model

Komunikasi Pariwisata yang Berbasiskan Kearifan Lokal. Jurnal The Messenger. 9(2). 231-240.

Rahmadi, F. (1999). Public Relations dalam Teori dan Praktek. Jakarta: PT Gramedia Pustaka.

Ri'aeni, Ida. (2015). Penggunaan New Media dalam Promosi Pariwisata Daerah Situs Cagar Budaya di Indonesia. Jumal komunikasi, ISSN 1907-898X. 9 (2). 187-197.

Sembiring, Junaidi Pranata. (2016). Strategi Komunikasi Pemasaran Objek Wisata Gundaling dan Pemandian Air Panas

Semangat Gunung. Jurnal Simbolika. 2 (1). Usman, H. (2009). Metodologi Penelitian Sosial. Jakarta: Bumi Aksara.

\section{Website:}

Humas Bandung. (15 Oktober 2019). Kecamatan Sumur Bandung Jadi Proyek Percontohan Co-Working Space. Retrieved October 22, 2019 from

http://humas.bandung.go.id/humas/beri ta/2019-10-15/kecamatan-sumurbandung-jadi-proyek-percontohan-co.

Mico Desrianto. (6 September 2019). Menpar Sumringah Posisi Indonesia di Peringkat Pariwisata Dunia Naik. Retrieved October 23, 2019 from https://travel.kompas.com/read/2019/09 /06/114334127/menpar-sumringahposisi-indonesia-di-peringkatpariwisata-dunia-naik?page $=$ all. 